\title{
Dietary Fibre from Whole Grains and Their Benefits on Metabolic Health
}

\author{
Nirmala Prasadi V. P. * and Iris J. Joye \\ Department of Food Science, University of Guelph, Guelph, ON N1G 2W1, Canada; ijoye@uoguelph.ca \\ * Correspondence: nvithana@uoguelph.ca
}

Received: 31 August 2020; Accepted: 30 September 2020; Published: 5 October 2020

\begin{abstract}
The consumption of whole grain products is often related to beneficial effects on consumer health. Dietary fibre is an important component present in whole grains and is believed to be (at least partially) responsible for these health benefits. The dietary fibre composition of whole grains is very distinct over different grains. Whole grains of cereals and pseudo-cereals are rich in both soluble and insoluble functional dietary fibre that can be largely classified as e.g., cellulose, arabinoxylan, $\beta$-glucan, xyloglucan and fructan. However, even though the health benefits associated with the consumption of dietary fibre are well known to scientists, producers and consumers, the consumption of dietary fibre and whole grains around the world is substantially lower than the recommended levels. This review will discuss the types of dietary fibre commonly found in cereals and pseudo-cereals, their nutritional significance and health benefits observed in animal and human studies.
\end{abstract}

Keywords: dietary fibre; cereals; pseudo-cereals; chronic diseases

\section{Introduction}

Consumers worldwide are interested in a healthy diet. Whole grain products, encompassing both cereals and pseudo-cereals, should constitute an important part of this healthy diet. The consumption of whole grain products is considered to have a beneficial effect on risk reduction of non-communicable diseases (NCD), including cardiovascular diseases, cancers, gastrointestinal disorders and type 2 diabetes [1-3]. It is widely accepted that it is through their high dietary fibre levels that these whole grain products play a very important role in the prevention and alleviation of NCDs. The term 'whole grain products' refers to products that are made with a relative proportion of bran, germ and endosperm tissue equal to what would naturally occur in intact grains [4].

According to the Cereals and Grains Association [5], 'whole grains consist of the intact, ground, cracked, flaked or otherwise processed kernel after the removal of inedible parts such as the hull and husk. All anatomical components, including the endosperm, germ, and bran must be present in the same relative proportions as in the intact kernel.'

Most cereal products that are currently on the market, however, are refined. Refined grain products are products that lack one or more parts of the integral kernel [6]. In the classical refining process for wheat e.g., the bran and the germ are separated from the starchy endosperm. The starchy endosperm is then further size-reduced to a fine white flour. Although during this process, the most functional part of a wheat kernel may be purified in the fine white flour to achieve the best quality end product, from a nutritional point of view, the refining process removes vital nutrients, dietary fibre and other phytochemicals from the other grain parts. As a result, the resulting refined products are of lower nutritional quality than the original whole grain products [7]. Therefore, the consumption of whole grain products, that have inherently a higher dietary fibre content than refined grain products and usually have a dietary fibre profile with a good balance between soluble and insoluble fibre components [8], undoubtedly can make a big difference in alleviation of risk on NCDs. 
Guidelines on recommended daily intake of whole grain products vary among countries. Canada's Food Guide [9] recommends replacing refined grain with whole grains, and the US dietary guidelines [10] recommend an optimal consumption level for wholegrain products of at least $85 \mathrm{~g}$ per day. The European Science Hub also emphasizes the importance of consumption of whole grain. Within the European Union, the different countries, however, have distinct guidelines [11]. The Swedish National Food Agency, e.g., recommends a daily consumption of about $70 \mathrm{~g}$ of whole grains for women, while $90 \mathrm{~g}$ is recommended for men. In Norway, a daily consumption of whole grain products is recommended, and the intake levels should reach 80 to $90 \mathrm{~g} /$ day [11]. According to research done by Micha and others [12], globally, the mean consumption of whole grain was only about $38 \mathrm{~g} /$ day. The values found on consumption of whole grain per country, however, varied widely, with values reported among 187 countries from 1990 to 2010, ranging from 1.3 to $334.3 \mathrm{~g} /$ day [12]. Overall, only 23 out of 187 countries displayed a mean whole grain consumption greater than 2.5 servings ( $\sim 50 \mathrm{~g})$ per day. The study indicated clearly that, on a global scale, whole grain consumption levels are far below the recommended levels (at least 2.5 servings/day).

\section{Dietary Fibre Present in Cereals and Pseudo-Cereals}

\subsection{Structure of Cereal Grains}

Wheat, barley, oats and rye belong, as all true cereals do per definition, to the grass family (Poaceae). This family is a very diverse family, covering plants that humans have used to grow a lawn to plants that can grow several meters tall (bamboo) [13]. Cereal grains have a complex structure that is characterized by different cell layers. Although the individual structural parts of the different cereal kernels may differ significantly in terms of composition and size, the general cereal structure remains largely the same [8]. Three main parts can be distinguished: the embryo or germ, the endosperm, and the outer kernel layers that cover the embryo and endosperm or the so-called bran [14]. The starchy endosperm accounts for $80-85 \%$ of the grain. It is mainly composed of starch and protein. Bran and germ represent $12-18 \%$ and $2-3 \%$ of the dry grain weight, respectively [15]. The embryo is vital for the germination process, as it comprises the embryonic axis and scutellum. The embryo has the highest content of lipids and lipid-soluble vitamins of all fractions in the cereal kernel [16]. The endosperm has the highest economic importance. In the endosperm insoluble nutrients, mainly starch and proteins, are deposited as an energy source for the developing plant upon germination [15]. The aleurone layer is the outermost layer of the endosperm. It usually consists of 1 to 3 layers of cells, depending on the cereal. In some cases, pigmentation in the aleurone layer can give cereal kernels a distinct colour [16]. Although botanically, the aleurone layer is considered to be part of the endosperm, a major part of this layer has been shown to be removed during roller milling and, hence, is often not part of the refined white cereal flour [17]. The bran fraction consists of several different layers that can be distinguished from one another, i.e., outer pericarp, inner pericarp, testa, and nucellar epidermis (also called hyaline layer) (Figure 1) [15]. Inner and outer pericarp are rich in highly crosslinked polysaccharides, such as cellulose, lignin and heteroxylan $[18,19]$. The testa of barley, oats and rice is present as one cell layer, while wheat and rye testas generally have two distinct layers [14]. The nucellar epidermis is the maternal tissue that covers the endosperm, but is not prominent in all cereals [16]. In sorghum, this layer is very prominently present, but it is usually absent or only present as a thin layer in most other cereals [20]. 


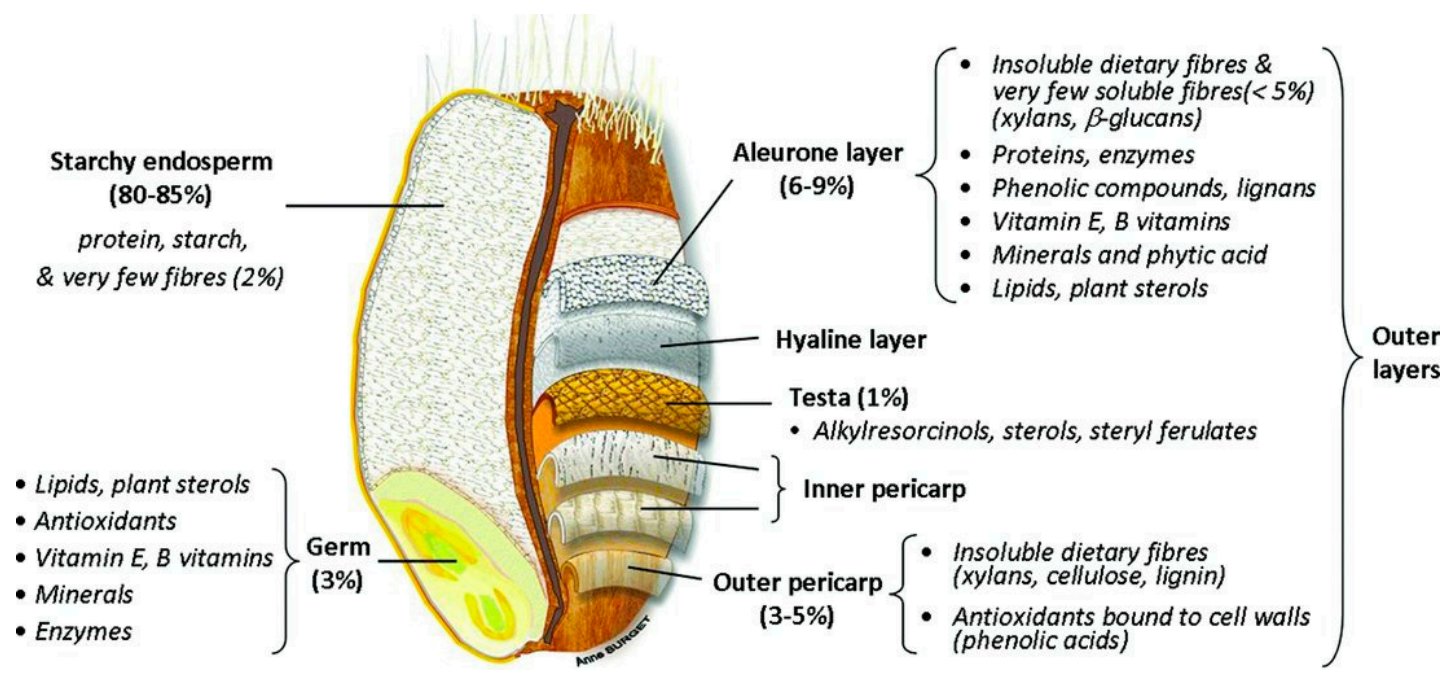

Figure 1. Wheat grain structure [21].

\subsection{Dietary Fibre Composition of Different Cereals}

Dietary fibres are defined as "carbohydrates with a degree of polymerization of 3 or more that naturally occur in foods of plant origin and that are not digested and absorbed by the small intestine" [22]. Dietary fibre can be classified according to its water solubility in insoluble dietary fibre (IDF) and soluble dietary fibre (SDF) [23]. IDF includes cellulose, water-insoluble hemicellulose and lignin, and are mainly present in plants as structural cell wall components [24]. SDF consists of a variety of non-cellulosic polysaccharides and oligosaccharides. Examples are pectins, $\beta$-glucans and water-soluble gums [25]. SDF and IDF differ largely in their functionality as food ingredients and their physiological effects upon consumption [23]. With regard to the latter, SDF, by increasing the viscosity of stomach and intestinal contents, is believed to reduce the overall intestinal enzymatic activity, and to decrease post-prandial plasma glucose levels [26,27]. In addition, SDF are highly fermentable and increase the production of short chain fatty acids (SCFAs), which are important contributors in the management of CVDs [28]. IDF, conversely, mainly serves as a bulking agent and laxative, hence, increasing faecal mass and decreasing intestinal transit time [29]. A potential mechanism of IDF related to management of NCDs might be related to increased satiety and reduction in body weight [28]. Both SDF and IDF help prevent constipation, decrease re-adsorption of bile salts, and lower the risk of colon cancer [25].

Dietary fibre can be obtained from different dietary sources, which include grains, fruits and vegetables. The amount and composition of dietary fibre can vary with the source [23]. Cereals are an important source of dietary fibre, contributing to about $50 \%$ of the total dietary fibre intake in Western countries [30]. Vegetables deliver about 30 to $49 \%$ of the daily dietary fibre intake, while fruits contributed about $16 \%$. Equal weights of fruits and vegetables contain less total dietary fibre relative to cereal grains, due to the higher moisture content. The proportion of IDF of the total dietary fibre varies depending on the type of fruit or vegetable that is studied [23]. Cellulose is the main component in the IDF fraction in plants, while pectin is a major fraction in the SDF fraction of fruits and vegetables [31].

\subsubsection{Dietary Fibre Composition of Wheat}

The total dietary fibre content of wheat ranges from 9 to about 20\% (dry weight basis), and is composed of both insoluble and soluble fractions (Table 1) [32,33]. The cell walls of the starchy endosperm cells in wheat are composed of two major types of dietary fibre components; i.e., arabinoxylan (AX) and $\beta$-D-glucan. These cell walls may also contain small amounts of cellulose and glucomannans [13]. The cellulose content in wheat endosperm is usually very low $(<5 \%)$ [32]. 
Cellulose is a linear polymer of $\beta-(1-4)$ linked glucose units, that associates with other cellulose molecules to form a highly insoluble network [33].

Hemicellulose is a prominent type of DF in grains. Hemicellulose is defined as the non-cellulosic component in cell walls consisting of heterogenic polysaccharides [34]. Hemicellulose molecules can be grouped largely into four categories: xylans, xyloglucans, glucomannans and mixed linkage $\beta$-glucans [34]. Hemicelluloses can be soluble or insoluble, depending upon their size and structure (e.g., side chain substitutions and intermolecular crosslinks) [35].

AX and mixed linked $\beta$-glucan account for about $70 \%$ and $20 \%$ of the total dietary fibre content, respectively. AX molecules are composed of a linear backbone of D-xylopyranosyl (Xyl) residues linked through $\beta$-(1-4) glycosidic linkages (Figure 2). Residues of $\alpha$-L-arabinofuranosyl (Ara) can be attached to the $\mathrm{Xyl}$ residues at the O-2 and O-3 positions (Figure 2). Four structural elements can, hence, be found in AX: non-substituted, O-2 or O-3 monosubstituted and disubstituted $\mathrm{Xyl}$ [36]. Ferulic acid can be esterified to arabinose residues on the O-5 position [37]. These ferulic acid structures can form bridges between AX chains, resulting in an increase of the AX molecular weight and a decrease in its water-extractability.

Table 1. Dietary fibre content (total, insoluble and soluble) of cereals and pseudo-cereals (g/100 g).

\begin{tabular}{|c|c|c|c|c|}
\hline & TDF & IDF & SDF & Reference \\
\hline \multirow{3}{*}{ Wheat (Triticum aestivum L., Triticum durum Desf.) } & $11.6-17.0$ & $10.2-14.7$ & $1.4-2.3$ & [38] \\
\hline & $10.2-15.7$ & $7.2-11.4$ & $1.9-2.9$ & [39] \\
\hline & 9.2 & - & - & [40] \\
\hline \multirow{3}{*}{ Oat (Avena sativa L.) } & $13.7-30.1$ & - & $11.5-20.0$ & [41] \\
\hline & 10.3 & 6.5 & 3.8 & [23] \\
\hline & $11.5-37.7$ & $8.6-33.9$ & $2.9-3.8$ & [42] \\
\hline \multirow{3}{*}{ Barley (Hordeum vulgare L.) } & $14.6-27.1$ & $12.0-22.1$ & $2.6-5.0$ & [42] \\
\hline & $16.8-27.9$ & - & - & [43] \\
\hline & 10.1 & - & - & [44] \\
\hline \multirow{2}{*}{ Rye (Secalecereale L.) } & $15.2-20.9$ & $11.1-15.9$ & $3.7-4.5$ & [32] \\
\hline & $14.7-20.9$ & $10.8-15.9$ & $3.4-6.6$ & [45] \\
\hline \multirow{2}{*}{ Rice (Oryza sativa L.) } & 9.9 & 5.4 & 4.4 & [46] \\
\hline & $2.7-4.9$ & $1.9-4.2$ & $0.6-1.1$ & [47] \\
\hline \multirow{2}{*}{ Corn (Zea mays L.) } & $3.7-8.6$ & $3.1-6.1$ & $0.5-2.5$ & [48] \\
\hline & $13.1-19.6$ & $11.6-16.0$ & $1.5-3.6$ & [42] \\
\hline \multirow{3}{*}{ Amaranth (Amaranthus spp.) } & $8.9-20.6$ & - & - & [49] \\
\hline & 11.4 & 7.7 & 3.7 & [50] \\
\hline & 11.8 & 9.1 & 2.7 & [51] \\
\hline \multirow{3}{*}{ Quinoa (Chenopodium quinoa Willd.) } & $7-9.5$ & $4.9-5.6$ & $2.1-3.9$ & [50] \\
\hline & $16.2-21.6$ & - & - & [52] \\
\hline & $11.6-15.1$ & $9.9-12.2$ & $0.4-2.9$ & [53] \\
\hline \multirow{2}{*}{ Buckwheat (Fagopyrumesculentum Moench.) } & 7.0 & 2.2 & 4.8 & [54] \\
\hline & 11.9 & 5.8 & 6.1 & [55] \\
\hline Teff [Eragrostis tef (Zucc.) Trotter] & 4.54 & - & 0.85 & [56] \\
\hline Sorghum (Sorghum bicolor) & $7.55-12.3$ & $6.52-7.90$ & $1.05-1.23$ & [57] \\
\hline Millets (Eleusine coracana (L.) Gaertn.) & $13.0-13.8$ & $12.5-13.2$ & $0.52-0.59$ & [58] \\
\hline
\end{tabular}

A significant part of the AX ( $>30 \%)$ in wheat endosperm is present as a water-extractable (WE) fraction $[59,60]$. The water-unextractable AX (WU-AX) are typically crosslinked to other polysaccharides or lignin molecules in cell walls [61]. The structure of WU-AX is very similar to that of WE-AX, but the average molecular weight and (to some extent) the Ara/Xyl ratio are higher for WU-AX than for WE-AX [60] $\beta$-D-glucan has a relatively simple structure in cereals, as it is only built up of one monosaccharide, i.e., $\beta$-D-glucose, that can be linked through either $\beta-1-4$ or $\beta-1-3$ linkages [8]. 


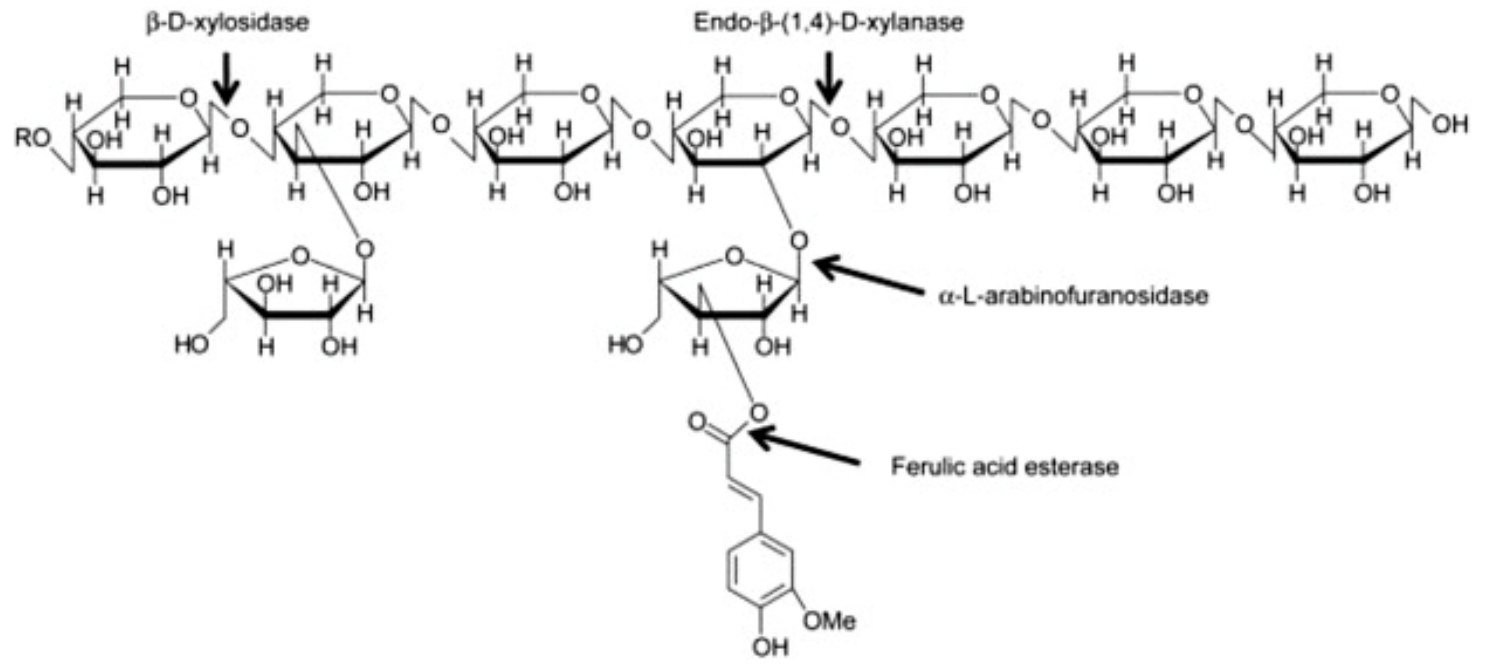

Figure 2. Structure of arabinoxylan [62].

Aleurone cells in wheat are characterized by thick cell walls. Relative to the starchy endosperm cell walls, the relative levels of AX and $\beta$-D-glucan in aleurone cell walls, however, remain the same [63]. $\mathrm{AX}$ in the aleurone layer, however, is highly esterified and crosslinked through diferulic acid bridges compared to starchy endosperm AX [64]. The pericarp cell wall composition is similar to the cell wall composition found in straw, characterized by highly branched AX. The AX in the pericarp also contain galactose and glucuronic acid residues and have a higher content of ferulic and diferulic acid residues [65].

\subsubsection{Dietary Fibre Composition of Barley and Oats}

Barley is one of the earliest cultivated cereals and exists in hulled and hulless varieties. Hulled barley can be dehulled after harvest prior to processing [7]. However, the hull from barley is not that easy to remove, as it is 'cemented' to the outer layer of the kernel or caryopsis, i.e., the pericarp [43]. In both hulled and hulless types, the caryopsis is composed of the pericarp, testa (seed coat), aleurone layer, endosperm, and embryo [7]. Oats, on the other hand, is also a hulled cereal, but its hull is relatively easy to remove. Barley and oats are an excellent source of soluble and insoluble dietary fibre and other bioactive compounds. Soluble dietary fibre (mainly $\beta$-glucan) is located in the endosperm cell walls, while the (predominantly) insoluble dietary fibre fraction (cellulose, AX and lignin) is mainly found in the cereal bran [66]. The total dietary fibre content of dehulled barley and oats ranges from 10 to $28 \%[43,44]$ and 10 to $38 \%$ [23,41,42] (on dry matter basis), respectively (Table 1). Both barley and oats contain $\beta$-glucan as the primary non-starch polysaccharide in the whole kernel. AX is also found in both cereals, but in a much lesser content. $\beta$-glucan and AX are typically present as 70 to $20 \%$ of the total dietary fibre content in these cereals. Cereal $\beta$-glucan is composed of cellotriosyl and cellotetraosyl units linked through $\beta-1-3$ linkages (Figure 3) [7]. The presence of such $\beta-1-3$ linkages leads to bends in the polymer chain structure, allowing water to get in between the chains [7]. This explains the higher solubility of $\beta$-glucan as compared to cellulose, a structurally related polymer built exclusively of $\beta$-1-4-linked D-glucose units [67].

The $\beta$-glucan content in oats and barley varies with the genotype. $\beta$-glucan is distributed uniformly throughout the endosperm in barley, while it is more concentrated in the outer layers of oats endosperm [68]. Whole grain barley can provide similar amounts of $\beta$-glucan as oats do. Hulless barley varieties and barley varieties with low amylose content can even provide 1.5 to 4 times more $\beta$-glucan as compared to oats [7].

As endosperm cell walls of barley and oats are rich in $\beta$-glucan, the $\beta$-glucan content of barley and oats may not decrease with the removal of the outer bran layers [7]. The soluble $\beta$-glucan content even increases in the function of dehulling, indicating the dominant endosperm distribution of $\beta$-glucan [69]. 


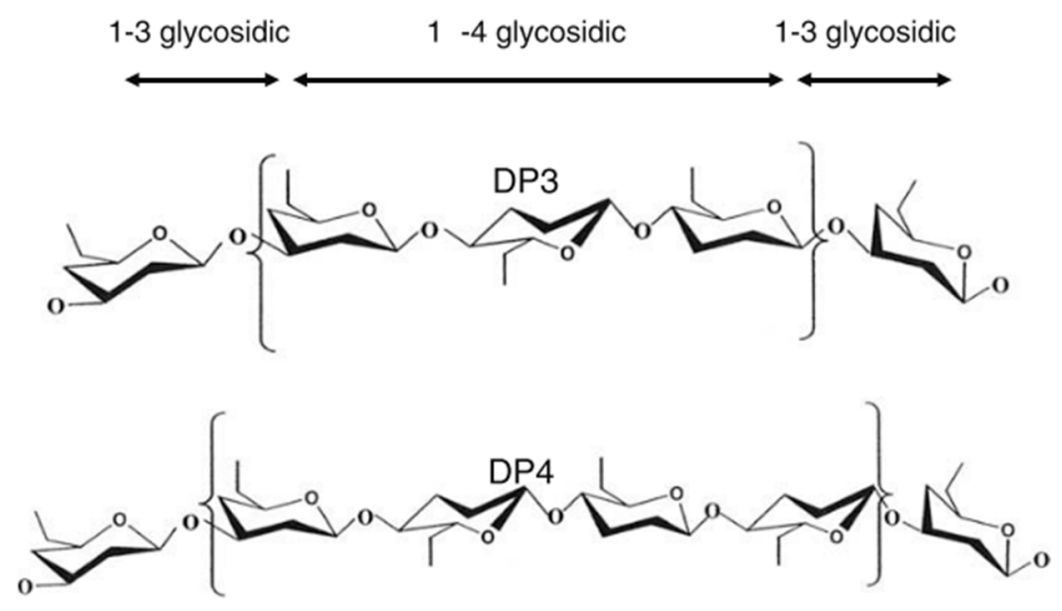

Figure 3. Molecular structure of cereal $\beta$-glucan [68].

\subsubsection{Dietary Fibre Composition of Rye}

The dietary fibre content of rye is higher compared to wheat, as rye contains about 14 to $21 \%$ dietary fibre (Table 1 ) on dry matter base [42,70]. AX, cellulose, fructan and $\beta$-glucan are the dominant dietary fibre types in rye, with AX being the major dietary fibre component (i.e., $45 \%$ of total dietary fibre content) present in endosperm cell walls [70]. Although both rye and wheat contain AX, the content and solubility of AX in rye is higher compared to AX found in wheat [34].

Rye contains the highest amount of fructan among the here-discussed cereals. Fructan is a soluble dietary fibre composed of $\beta$-D-fructofuranosyl units, with or without terminal glucose residue [71]. Fructans of rye can be linear or branched in structure. A typical degree of polymerization of fructan in rye ranges anywhere from 2 to 60 [72].

The level of dietary fibre present in rye varies in function of its location within the kernel. The inner endosperm contains less dietary fibre $(12 \%)$, while the outer endosperm and bran fraction contain about 22 and 38\% dietary fibre on dry matter basis, respectively [73]. The higher levels of dietary fibre found in the outer kernel layers of rye are another illustration of the importance of eating whole grains.

\subsubsection{Dietary Fibre Composition of Other Grains}

The dietary fibre content of rice (whole grain) varies from 2.7 to 9.9\% (Table 1). This high variation in dietary fibre content is partially related to differences found in between rice varieties [34,47]. The dietary fibre content of brown rice is higher than the content found in white rice, in which, essentially, the outer kernel layers have been removed by abrasive milling. As is the case with the other cereals, the dietary fibre is also mainly found in the hull and bran of rice kernels [74]. In rice (whole grain), the major components of the IDF fraction are cellulose and water insoluble hemicellulose, while soluble AX and $\beta$-glucan make up the SDF fraction [75].

The dietary fibre content of corn varies between 3.7 and $19.9 \%$ on dry matter basis [42,76], of which IDF is the largest fraction (Table 1) [38]. Cellulose and hemicellulose are the main IDF fractions found in corn bran [76].

\subsection{Structure of Pseudocereal Grains}

Pseudocereals are largely underutilized crops that have recently been gaining attention due to the nutritional properties that are associated with them. Pseudocereals can be processed into, and used as, a flour, in a very similar way to the way in which wheat is processed and used. The three pseudocereals that have been most widely studied thus far are amaranth (Amaranthus spp; Amaranthceae), quinoa (Chenopodium quinoa subsp. quinoa; Chenopodiaceae), and buckwheat (Fagopyrum esculentum; Polygonaceae) [55]. These are dicotyledonous plants, as opposed to cereals like wheat, rice and barley, which are monocotyledonous [77]. 
Pseudocereal seeds are, similarly to cereals, also composed of several 'layers' (Figure 4). Perisperm, germ and endosperm are the three main areas containing food reserves in pseudocereals [76]. The kernel and 'layer' composition varies for the different pseudocereals.

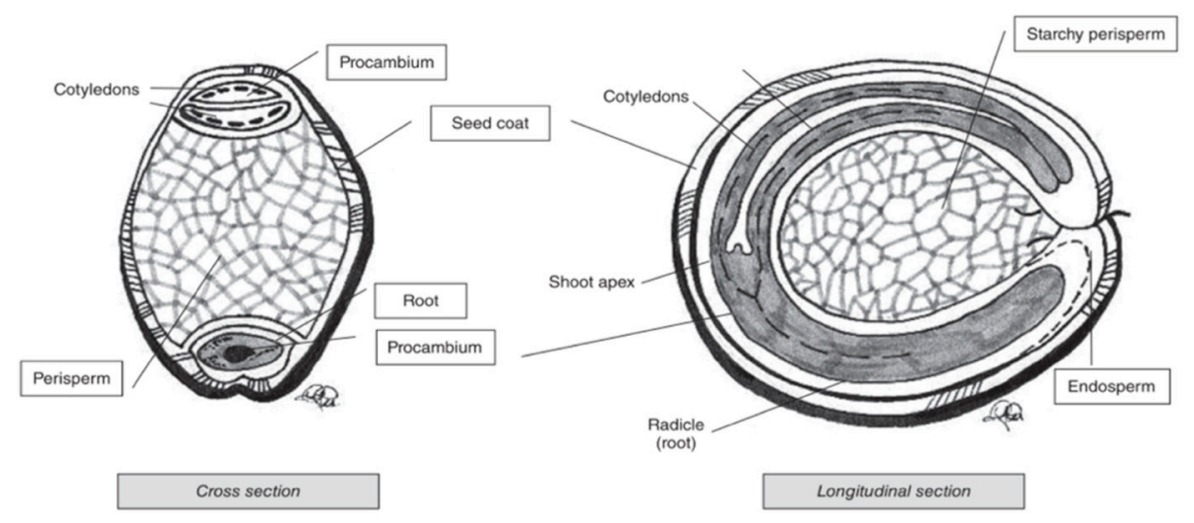

Figure 4. Cross and longitudinal section of amaranth seed [76].

Amaranth is a small seed with diameters ranging from around 0.9 to $1.7 \mathrm{~mm}$ [76]. The major portion of the seed is the embryo, which is twisted in a circle. The embryo is large and encloses the perisperm and consists of the radicle and cotyledons, which is the main protein storage organ of the seed [78]. The seed coat is completely smooth and thin, and its colour can be white, cream, gold-yellow and even brown [55]. Quinoa kernels have the same structure as amaranth kernels. It produces small, spherical-shaped seeds, with diameters that vary between 1.0 and $2.6 \mathrm{~mm}$. One gram of quinoa contains about 250 to 500 seeds [79]. Similar to what is the case for amaranth, the main storage tissues of quinoa seeds are the perisperm, embryo and cotyledons [80]. Buckwheat seed is pyramid-shaped with sizes ranging from 4 to $9 \mathrm{~mm}$ [79]. The seed is covered with a dull brown or grey pericarp that is tightly attached to the seed [81]. The embryo is embedded in the centre of the endosperm and has two cotyledons [82].

\subsection{Dietary Fibre Composition of Pseudocereals}

Amaranth, quinoa and buckwheat are pseudocereals with a long history of utilization as food ingredients and have very interesting nutritional characteristics. Pseudocereals have been gaining popularity in the last decade as ingredient for gluten-free products. Their use substantially increases the dietary fibre content of these products, which are typically deficient in dietary fibre [49]. Although the dietary fibre content varies between amaranth species, the total dietary fibre content of amaranth varies between 9 and 21\% (dry weight basis) [83,84], while quinoa contains around 7 to 21\% TDF [50,52,53]. Based on a monosaccharide analysis of dietary fibre extracted from amaranth and quinoa samples, the dietary fibre in these pseudocereals is mainly composed of galacturonic acid, arabinose, xylose, glucose and galactose. According to this monosaccharide composition and analysis of the linkages, the dominant fraction of both the soluble and insoluble dietary fibre in these pseudocereals is classified as pectic polysaccharide [85]. Xyloglucans are the second most prominent dietary fibre present in amaranth and quinoa whole grains. Cell walls of amaranth also contain significant amounts of phenolic acids. High levels of ferulic acid were found, while coumaric acid and caffeic acid are also present, but in lower amounts [78]. Both quinoa and amaranth have a high proportion ( $22 \%$ of the total dietary fibre content) of SDF compared to wheat (about $15 \%$ ), indicating promising potential with regard to colon health [86].

The total dietary fibre content of buckwheat groats (7-11.9\%) is lower than the dietary fibre content found in most cereals such as wheat, barley and oats (Table 1$)$. The majority $(\sim 70 \%)$ of dietary fibre from buckwheat groats is water insoluble [82]. The water soluble fibre of buckwheat seeds is mostly 
classified as pectin, arabinogalactan and xyloglucan [81]. Pectin was found in the cell walls of the outer and inner epidermis, and the endosperm of buckwheat seeds [81].

\section{Dietary Fibre from Whole Grains and Health Implications}

Many health benefits associated with the consumption of whole grains are ascribed to the higher dietary fibre content in whole grain ingredients, as opposed to the levels found in refined cereal ingredients. Whole grains provide a good balance of soluble and insoluble fibre (Table 1).

A meta-analysis done by Huang et al. [87] showed that a high consumption of whole grains or cereal fibre could be related to a reduced risk of NCDs.

\subsection{Cardiovascular Health}

Atherosclerosis and subsequent cardiovascular complications, such as myocardial infarction, stroke, and heart failure, are leading causes of death worldwide [88]. Multiple factors have been identified as risk factors for the development of CVDs. These risk factors include both non-modifiable risk factors (e.g., age, gender, and family history) and modifiable risk factors (e.g., lipid profile, blood pressure, hyperglycemia etc.) [89]. According to Health Canada, heart diseases are the second leading cause for deaths in Canada [90]. The beneficial effects of dietary fibre consumption on CVD protection have been well-documented in both animal and human studies. The protective effect of dietary fibre on CVDs may be due to the ability of SDF to form viscous gels. Increasing the viscosity of the gut content reduces the reabsorption of bile acids which, on its turn, reduces the circulation of cholesterol in blood. SDF also triggers the formation of short chain fatty acids (SCFA) by colon bacteria [91]. These SCFAs include butyrate, acetate and propionate and have different functional properties in the human body. Butyrate, for example, is known to reduce the progression of atherosclerosis, while propionate is known to inhibit cholesterol synthesis and its accumulation in the liver [92]. High blood cholesterol levels were identified as a risk factor for the incidence of CVDs [62]. Cereal $\beta$-glucan is one of the main types of SDF that have an effect on CVD prevalence. After considering the scientific evidence, the Food and Drug Administration (FDA) allowed a health claim that soluble fibre from oats may reduce the risk of heart diseases [93].

Several studies using animal models have indicated that AX have the potential to reduce blood serum triglyceride and cholesterol levels, both considered to be important modifiable risk factors for CVD [94]. One such study focused on hypercholesterolemic hamsters. Supplementation of the feed with extracted AX from wheat bran (alkaline extraction) reduced the total and LDL cholesterol levels in these hamsters [95]. Moreover, the AX supplementation led to increased propionate and total short-chain fatty acids (SCFAs) concentrations in the colon [66].

In another study, five week old mice were fed with a lard based high fat diet for one week, after which the diet was substituted with enzyme treated wheat bran (wheat bran was treated with xylanase and cellulase to increase the soluble AX content). A significant reduction in body weight and liver triglyceride content was observed with the administering of enzyme treated wheat bran [96]. This supplementation has also altered the gut microbiota composition [7]. In a rat study, a decrease in plasma cholesterol levels and an increase in SCFA levels in portal vein was found when refined wheat flour was substituted with whole wheat flour in the diets that were fed to the rats [97]. Research on pseudocereals carried out by Konishi et al. [98] reported that a diet supplemented with quinoa pericarp significantly reduced liver cholesterol in mice. Similarly, a cholesterol lowering effect was also found when hypercholesterolemic rabbits were fed with extruded amaranth products [99]. In these rabbits, reductions in the levels of total cholesterol, LDL-cholesterol, VLDL-cholesterol, and triacylglycerols in plasma were observed after feeding a diet with extruded amaranth for 21 days [67].

According to a study carried out with 34,492 postmenopausal women that were monitored for 6 years, a higher intake of whole grains was associated with a reduced death rate due to CVD. In another experiment using a nurses' health study, a strong inverse relationship between whole grain consumption and risk of CVD was observed [100]. Another cohort study evaluated the association between the 
dietary fibre type and cardiovascular risk factors in a Spanish working population [101]. This study pointed to an inverse relationship between IDF intake and total cholesterol and blood pressure, while SDF intake inversely affected the triglyceride content [101] when analysing the blood samples.

In an intervention study, a diet rich in barley $\beta$-glucan was administered to mildly hypercholesteremic subjects (25 subjects) [102]. A reduction in total plasma cholesterol content was observed for the test population that was fed a diet containing 3 to $6 \mathrm{~g}$ of $\beta$-glucan from barley compared to those subjects that were administered a diet that did not contain $\beta$-glucan [102]. In another study, $\beta$-glucan was administrated in three levels, i.e., low (only whole wheat flour), medium (50:50 whole wheat flour: barley flour) and high (only barley flour) $\beta$-glucan level. Total cholesterol levels were 4,9 , and $10 \%$ down, respectively, after consuming the low, medium and high $\beta$-glucan diets compared to what was detected for the subjects that were fed a control diet [103]. A meta-analysis performed on 28 randomized control trials that used at least $3 \mathrm{~g}$ of oat $\beta$-glucan per day to evaluate cholesterol lowering effects concluded that these levels of oat $\beta$-glucan can reduce both low density lipoprotein (LDL) and total cholesterol levels. The above specified $\beta$-glucan dose, on the other hand, did not shown any significant impact on the level of high-density lipoproteins (HDL) [104].

A high dietary fibre intake has also been shown to affect the incidence of hypertension, another risk factor associated with CVDs [105]. Several studies suggested that the consumption of SDF provides a safe way to reduce blood pressure [106-108]. In a Mediterranean cohort study, an inverse relation was found between cereal fibre intake and the risk of hypertension [109]. Another cohort study was evaluating the effect of the type of dietary fibre on risk factors in a Spanish working population and found an inverse relationship between IDF consumption and systolic and diastolic blood pressure [101].

In a randomized parallel group study involving hypertensive men and women, eating either a low fibre cereal diet or a high fibre oat meal, a significant reduction in systolic and diastolic blood pressure was observed for the high fibre diet consuming test subjects [110]. In a study to understand the effect of dietary fibre type on blood pressure reduction, a significant reduction in blood pressure was observed for food containing higher total dietary fibre and IDF levels [105]. However, additional studies are still needed to confirm these findings [111].

\subsection{Blood Glucose Levels}

Diabetes is a chronic condition during which the human body loses its ability to produce or properly use insulin. There are three common types of diabetes: type 1, type 2 and gestational diabetes. About $90 \%$ of the diabetes cases in Canadian adults are identified as type 2 . Type 2 diabetes is a metabolic disorder caused by a low insulin production by the pancreas [112]. Among many other factors, the diet has been identified as an important aspect in managing type 2 diabetes. Diabetes or elevated glucose levels in blood are also considered risk factors for CVDs [89].

Dietary fibre from cereals was found to be effective in reducing the postprandial blood glucose response (i.e., blood glucose levels after a meal) and increasing the insulin response [113]. As outlined above, soluble dietary fibre has the capacity to increase the viscosity of stomach content. An increase in the viscosity of the gut content caused by cereal dietary fibre plays a major role in reducing glucose absorption [27]. The higher viscosity also slows the gastric emptying process down and reduces the rate of starch digestion (and associated mono- and disaccharide production) and, hence, causes a delay in glucose absorption [114]. The slower digestion rate can also be the result of the formation of a 'thick layer' around the food bolus, that reduces the access digestive enzymes have to the inner part of the food bolus and hinders contact with absorbing surfaces in the gastrointestinal tract $[115,116]$. Even though SDF are considered to display anti-diabetic effects, it has been found that IDF are more potent in reducing the risk of type 2 diabetes $[117,118]$. It is believed that fermentation and secondary metabolites play a role in the mentioned effect [119]. The mechanisms behind these benefits of IDF need to be studied further.

Studies on pseudocereals, such as amaranth, showed that its consumption may also reduce the blood serum glucose levels and increase insulin levels in diabetes-induced rats [120]. When fed 
extruded amaranth snacks with a high fibre content, a reduced glycemic response was observed, relative to what was measured for a control population that was fed white bread [78]. However, some studies have shown that amaranth consumption could actually increase the glycemic response [78,121]. This study compared the in vitro starch digestibility of processed amaranth seeds to that of white bread. Cooked, extruded, and popped amaranth seeds had a starch digestibility similar to that of white bread while flaked and roasted seeds generated a slightly increased glycemic response [80]. These opposing results may be related to differences in the processing conditions and the associated changes induced in the dietary fibre fraction and starch in the different studies.

According to a meta-analysis of a cohort study done by Schulze and others, the intake of dietary fibre of cereal origin associates inversely with the risk of diabetes development [118]. Another study focusing on the association between intake of dietary fibre and type 2 diabetes is the European Prospective Investigation into Cancer and Nutrition (EPIC)-InterAct study [122]. This study revealed that there is an inverse relationship between the total and cereal dietary fibre consumption and the risk of developing type 2 diabetes [122].

Cereal $\beta$-glucan has been studied extensively to evaluate its effect on blood glucose responses after consuming a meal. In a study carried out with test subjects with and without type 2 diabetes, a meal with native cell wall fibre from oat bran and extracted oat gum reduced the postprandial blood glucose levels compared to a wheat farina meal [123]. In another study, a meta-analysis performed using four articles studying a total of 350 subjects, a relation was found between the consumption of oat $\beta$-glucan and a reduction of plasma glucose levels [124]. Consumption of AX has also been related to a significant reduction of the postprandial glucose response [114]. Soluble AX was found to reduce the rate of the gastric emptying process, hence reducing the absorption of glucose [125]. Plasma glucose levels were measured after administering AX-enriched and control white bread, in a double-blind crossover study design using human subjects. Postprandial glucose concentrations observed after AX-enriched meals were significantly lower than what was found for those subjects that were eating the control meal [126]. Similar to what was outlined above for $\beta$-glucan, the viscosity increasing effect of AX exerted beneficial effects on glycemia and insulinemia (i.e., presence of high concentration of insulin in blood) [127]. As AX is a major component of the dietary fibre fraction in many cereals, the consumption of any type of whole cereal grain is believed to unlock the health benefits that are associated with AX [128].

The effect of IDF on prevention of diabetes has also been recognized in recent studies. Even though the mechanism is not yet fully understood, the effect may be related to an increased satiety and changes in body weight [129]. The consumption of IDF levels according to the recommended levels has helped to accelerate the early insulin response, and is also associated with a significant reduction in postprandial glucose value [28]. Large cohort studies pointed to the possibility that IDF from cereals may reduce the risk of developing type 2 diabetes $[129,130]$. Researchers have been observing, however, largely contrasting results in this field, clearly illustrating the need for more studies [131].

\subsection{Gastrointestinal Health}

Dietary fibre can positively affect gastrointestinal health. Whole grains are rich in dietary fibre and usually have a lower energy density. Dietary fibre also plays a vital role in providing a suitable environment for gut microbiota by acting as prebiotics. Prebiotics are ingredients that are resistant to gastric acidity and hydrolysis by enzymes. They can be fermented in the colon, hence, changing the composition of the gut microbiota [132].

According to the Canadian Cancer Society, colorectal cancer is recognized as the third most commonly diagnosed cancer in Canada [133]. Many studies thus far have focused on finding a correlation between the prevalence of colorectal cancer and the consumption of dietary fibre. A strong theoretical base to prove this correlation exists as dietary fibre dilutes faecal carcinogen and procarcinogen concentrations. In addition, it also reduces the residence time of the carcinogens in the lower gastrointestinal tract, reducing their absorbance [90]. Dietary fibre present in whole grains 
can be degraded by bacterial enzymes in the human colon to produce SCFA. SCFA have shown to exhibit protective effects against the growth of tumour cells [134]. According to a meta-analysis done to evaluate the association between dietary fibre and colorectal cancer incidence, an increase of the cereal dietary fibre intake with about $10 \mathrm{~g} /$ day is associated with a $9 \%$ decrease in risk on colorectal cancer [135].

Inflammatory bowel disease (IBD) is a chronic disease characterized by a painful inflammation of the small and large intestine. The most commonly occurring IBDs are Crohn's disease and ulcerative colitis [136]. Crohn's disease can cause inflammation in any part of the gastrointestinal tract, while ulcerative colitis causes inflammation in the large intestine [137]. Studies have described the positive effects of dietary fibre present in whole cereal grains on gut microflora. One study, for example, positively evaluated the effect of oats $\beta$-glucan on Crohn's disease in rats [138]. The presence of various types and lengths of dietary fibre was found to be crucial to these positive effects [136]. According to macroscopic and microscopic analysis, both low and high molecular weight $\beta$-glucan are able to reduce the macroscopic and microscopic lesions occurring in mucosal and submucosal layers of the colon in rats with induced colitis [136]. $\beta$-glucan supplementation of the diet increases the levels of beneficial lactic acid bacteria and increases the SCFA content in rat faeces. This will reduce the growth of pathogenic microflora and the production of toxic metabolites in the colon [136]. Although both high and low molecular weight $\beta$-glucan were shown to exert positive effects, the effectiveness in inhibiting mucosal infections was higher for the high than the low molecular weight $\beta$-glucan samples [136]. Dietary fibre has shown to attenuate experimental colitis in animal models. However, some large cohort studies could not support the claimed involvement of dietary fibre in the prevention of ulcerative colitis $[139,140]$. This clearly indicates the need for future work to investigate long term effects of the consumption of dietary fibre types on IBD.

The consumption of dietary fibre plays a very important role in maintaining healthy gut microbiota [141]. The symbiotic relationship among gut microbiota and the human being plays a crucial role in risk reduction of NCDs, including IBD and colorectal cancers [142]. Dietary fibre helps in preserving the diversity of gut microbiota [143]. A lack of dietary fibre in our daily diet reduces the diversity of this gut microbial community [144]. Similarly, due to this diverse nature, the human gut microbiome contains diverse microbial genomes which produce thousands of enzymes targeting dietary fibre [145]. This results in the formation of a number of metabolites from dietary fibre conversion in the GIT, including SCFAs that are believed to help managing NCDs [144].

Another well-known function of dietary fibre is promoting laxation and preventing constipation. An increased intake of dietary fibre can indeed prevent and/or manage the prevalence and severity of constipation and haemorrhoids [146]. Wheat bran and high fibre cereal fractions are commonly recommended to prevent constipation. The water holding capacity of these dietary fibre fractions plays an important role in the laxative properties, as it leads to faecal bulking. According to Cummings [147], the ability of dietary fibre to result in faecal bulking varies with the dietary fibre type. As an example, the faecal weight increase per gram of administered wheat bran is about $5.4 \mathrm{~g}$, while whole oats increase the faecal weight by $3.4 \mathrm{~g}$ per gram of administered oats in human studies.

\subsection{Obesity and Weight Management}

There is strong epidemiological evidence linking the consumption of dietary fibre (more specifically the intake of whole grains) to overweight and obesity mitigation. The main effect behind this effect, may be a reduced appetite and prolonged satiety feeling after consumption of these products [148]. An inverse association was observed between wholegrain consumption levels, on the one hand, and body mass index (BMI) and risk of overweight and obesity in men as well as women, on the other hand, in a cohort study carried out in the Netherlands [149]. The association in men was found to be stronger than the association found for the female participants [149]. A cross-cultural study of 16 cohorts in seven countries showed that the BMI and subscapular skin fold thickness were inversely associated 
with total dietary fibre intake, suggesting that a reduced intake of fibre was an important determinant in the storage of body fat [150].

Studies have demonstrated that $\beta$-glucan consumption can enhance the postprandial satiety feeling, and reduce the body weight, BMI and total energy intake [151,152]. In another study, a meta-analysis was done using 20 studies to evaluate the effect of cereal $\beta$-glucan consumption on body weight, BMI and anthropometrics [153]. The study confirmed that the consumption of $\beta$-glucan from cereal sources leads to a significant reduction of body weight and BMI. Possible mechanisms for the prolonged satiety feelings may be linked to the gel forming ability of soluble $\beta$-glucan and other soluble fibres, and the bulking effect of insoluble fibres [154]. In addition, a release of appetite suppressants such as cholecystokinin was shown in response to the consumption of $\beta$-glucan at a minimum dose of $3.8 \mathrm{~g}$ per day, in a study done using 14 human subjects ( 7 male and 7 female) [155].

\subsection{Undesirable Effects Associated with Consumption of Dietary Fibre}

Although the above suggests that dietary fibre is exclusively associated with beneficial effects on human health, the intake of dietary fibre may also cause negative effects on mineral and overall micronutrient absorption [24]. Several in vitro studies have shown that both IDF and SDF display mineral binding properties to various extents [156]. Mineral binding properties vary with the type of fibre, concentration and with $\mathrm{pH}$ and ionic strength [157]. Similarly, dietary fibre may alter the bioavailability of vitamin [158]. The bioavailability of different kinds of vitamin B was studied, and it was observed that their bioavailability can vary with the characteristics of dietary fibre (type, molecular weight and the content [159]. Research suggests that various types of dietary fibre (hemicellulose, lignin and pectin) reduce the bioavailability of $\beta$-carotene in human subjects [160].

\section{Conclusions}

Persons who consume a higher number of servings of whole grain foods as a source of dietary fibre are at lower risk for developing coronary heart diseases, diabetes, obesity and certain gastrointestinal disorders. However, even though the benefits of dietary fibre consumption are documented well, the consumption of dietary fibre is still below the recommended levels. The same is true for the consumption of whole grain products.

Whole grains of cereals and pseudocereals contain a wide variety of dietary fibre types. Some examples of cereal dietary fibre types are arabinoxylan, $\beta$-glucan, xyloglucan, pectic polysaccharides and fructan. Cereal dietary fibre exists as both soluble and insoluble dietary fibre fractions. Different cereals have typically a different dietary fibre profile. Wheat grain e.g., is rich in AX, while barley and oats are recognized for the functional properties associated with their most important dietary fibre type, i.e., $\beta$-glucan. One of the main effects of soluble dietary fibre is increasing the viscosity of the gut content. In contrast, insoluble dietary fibre absorbs more water and helps in faecal bulking.

Benefits of dietary fibre from cereals and pseudo-cereals have been studied throughout the years. Intake of some of the dietary fibre types such as oat $\beta$-glucan have been recommended due to approved health benefits, while many other types of dietary fibre are still studied for their specific effects. Because these health benefits are interconnected, often synergistic and individu-specific, it is difficult to obtain solid evidence of the health effects per dietary fibre. However, more research and communication on these health benefits is needed to translate the science behind these beneficial effects into useful information for broader public health advice for people seeking healthy eating patterns.

Funding: This research was funded by the Ontario Ministry of Agriculture, Food and Rural Affairs (OMAFRA) under the Alliance-Tier 1 program.

Conflicts of Interest: The authors declare no conflict of interest. 


\section{References}

1. Barrett, E.M.; Foster, S.I.; Beck, E.J. Whole grain and high-fibre grain foods: How do knowledge, perceptions and attitudes affect food choice? Appetite 2020, 149. [CrossRef]

2. Reynolds, A.; Mann, J.; Cummings, J.; Winter, N.; Mete, E.; Te Morenga, L. Carbohydrate quality and human health: A series of systematic reviews and meta-analyses. Lancet 2019, 393, 434-445. [CrossRef]

3. He, M.; Van Dam, R.M.; Rimm, E.; Hu, F.B.; Qi, L. Response to letter regarding article, whole-grain, cereal fiber, bran, and germ intake and the risks of all-cause and cardiovascular disease-specific mortality among women with type 2 diabetes mellitus. Circulation 2011, 123. [CrossRef]

4. Barrett, E.M.; Batterham, M.J.; Ray, S.; Beck, E.J. Whole grain, bran and cereal fibre consumption and CVD: A systematic review. Br. J. Nutr. 2019, 121, 914-937. [CrossRef]

5. van der Kamp, J.W.; Poutanen, K.; Seal, C.J.; Richardson, D.P. Whole grain. In Definitions; Cereals \& Grains Association, 2019. Available online: https://www.cerealsgrains.org/initiatives/definitions/Pages/WholeGrain. aspx (accessed on 17 September 2020).

6. Definition of a Whole Grain. The Whole Grains Council. Available online: https://wholegrainscouncil.org/ definition-whole-grain (accessed on 18 May 2020).

7. Newman, C.W.; Newman, R.K.; Fastnaught, C.E. Barley. In Whole Grains and Their Bioactives: Composition and Health; Johnson, J., Wallace, T., Eds.; John Wiley \& Sons: Hoboken, NJ, USA, 2019; pp. 135-167.

8. Delcour, J.A.; Poutanen, K. Fibre-Rich and Wholegrain Foods: Improving Quality; Woodhead Publishing: Cambridge, UK, 2013.

9. Health Canada. Canada's Food Guide; Health Canada: Ottawa, ON, Canada, 2011. [CrossRef]

10. Slavin, J. Dietary guidelines: Are we on the right path? Nutr. Today 2012, 47, 245-251. [CrossRef]

11. EU-Joint Research Centre. Health Promotion and Disease Prevention. Available online: https://ec.europa.eu/ jrc/en/health-knowledge-gateway/promotion-prevention/nutrition/whole-grain (accessed on 1 August 2020).

12. Micha, R.; Khatibzadeh, S.; Shi, P.; Andrews, K.G.; Engell, R.E.; Mozaffarian, D. Global, regional and national consumption of major food groups in 1990 and 2010: A systematic analysis including 266 country-specific nutrition surveys worldwide. BMJ Open 2015, 5. [CrossRef] [PubMed]

13. Evers, A.D.; Blakeney, A.B.; O’Brien, L. Cereal structure and composition. Aust. J. Agric. Res. 1999, 50, 629-650. [CrossRef]

14. Liu, K. Physical properties of DDGS. In Distillers Grains: Production, Properties, and Utilization; Liu, K., Kurt, A.R., Eds.; AOCS Publishing: Urbana, IL, USA, 2016; pp. 121-142.

15. Brouns, F.; Hemery, Y.; Price, R.; Anson, N.M. Wheat Aleurone: Separation, Composition, Health Aspects, and Potential Food Use. Crit. Rev. Food Sci. Nutr. 2012, 52, 553-568. [CrossRef] [PubMed]

16. Evers, T.; Millar, S. Cereal grain structure and development: Some implications for quality. J. Cereal Sci. 2002, 36, 261-284. [CrossRef]

17. Dexter, J.E.; Wood, P.J. Recent applications of debranning of wheat before milling. Trends Food Sci. Technol. 1996, 7, 35-41. [CrossRef]

18. Barron, C.; Surget, A.; Rouau, X. Relative amounts of tissues in mature wheat (Triticum aestivum L.) grain and their carbohydrate and phenolic acid composition. J. Cereal Sci. 2007, 45, 88-96. [CrossRef]

19. Rosa-Sibakov, N.; Poutanen, K.; Micard, V. How does wheat grain, bran and aleurone structure impact their nutritional and technological properties? Trends Food Sci. Technol. 2015, 41, 118-134. [CrossRef]

20. Liu, K. Structure and Grain Composition. In Distillers Grains: Production, Properties, and Utilization; Liu, K., Rosentrater, K.A., Eds.; AOCS Publishing: Urbana, IL, USA, 2016; pp. 45-69.

21. Surget, A.; Barron, C. Histologie du grain de bl'e. Ind. des C'er'eales 2005, 145, 3-7.

22. Health Canada. List of Dietary Fibres Reviewed and Accepted by Health Canada's Food Directorate-Canada.ca. Available online: https://www.canada.ca/en/health-canada/services/publications/ food-nutrition/list-reviewed-accepted-dietary-fibres.html (accessed on 12 August 2020).

23. Dhingra, D.; Michael, M.; Rajput, H.; Patil, R.T. Dietary fibre in foods: A review. J. Food Sci. Technol. 2012, 49, 255-266. [CrossRef]

24. Li, Y.O.; Komarek, A.R. Dietary fibre basics: Health, nutrition, analysis, and applications. Food Qual. Saf. 2017, 1, 47-59. [CrossRef]

25. Dai, F.J.; Chau, C.F. Classification and regulatory perspectives of dietary fiber. J. Food Drug Anal. 2017, 25, 37-42. [CrossRef] 
26. Ahmad, A.; Anjum, F.M.; Zahoor, T.; Nawaz, H.; Dilshad, S.M.R. Beta glucan: A valuable functional ingredient in foods. Crit. Rev. Food Sci. Nutr. 2012, 52. [CrossRef]

27. Wood, P.J. Cereal $\beta$-glucans in diet and health. J. Cereal Sci. 2007, 46, 230-238. [CrossRef]

28. Weickert, M.O.; Pfeiffer, A.F. Impact of dietary fiber consumption on insulin resistance and the prevention of type 2 diabetes. J. Nutr. 2018, 148, 7-12. [CrossRef]

29. Lattimer, J.M.; Haub, M.D. Effects of dietary fiber and its components on metabolic health. Nutrients 2010, 2, 1266-1289. [CrossRef]

30. Cooke, R. ProQuest Ebook Central. Charlest. Advis. 2017, 19, 39-43. [CrossRef]

31. Esteban, R.M.; Mollá, E.; Benítez, V. Sources of Fiber. In Dietary Fiber for the Prevention of Cardiovascular Disease: Fiber's Interaction between Gut Micoflora, Sugar Metabolism, Weight Control and Cardiovascular Health; Academic Press: London, UK, 2017; pp. 121-146.

32. Gartaula, G.; Dhital, S.; Netzel, G.; Flanagan, B.M.; Yakubov, G.E.; Beahan, C.T.; Collins, H.M.; Burton, R.A.; Bacic, A.; Gidley, M.J. Quantitative structural organisation model for wheat endosperm cell walls: Cellulose as an important constituent. Carbohydr. Polym. 2018, 196, 199-208. [CrossRef] [PubMed]

33. Padayachee, A.; Day, L.; Howell, K.; Gidley, M.J. Complexity and health functionality of plant cell wall fibers from fruits and vegetables. Crit. Rev. Food Sci. Nutr. 2017, 57, 59-81. [CrossRef] [PubMed]

34. Ciudad-Mulero, M.; Fernández-Ruiz, V.; Matallana-González, M.C.; Morales, P. Dietary fiber sources and human benefits: The case study of cereal and pseudocereals. Adv. Food Nutr. Res. 2019, 90, 83-134. [PubMed]

35. Sharma, P.; Bhandari, C.; Kumar, S.; Sharma, B.; Bhadwal, P.; Agnihotri, N. Dietary Fibers: A Way to a Healthy Microbiome. Diet Microbiome Health 2018, 299-345.

36. Izydorczyk, M.S.; Dexter, J.E. Barley b-glucans and arabinoxylans: Molecular structure, physicochemical properties, and uses in food products-A Review. Food Res. Int. 2008, 41, 850-868. [CrossRef]

37. Aguedo, M.; Fougnies, C.; Dermience, M.; Richel, A. Extraction by three processes of arabinoxylans from wheat bran and characterization of the fractions obtained. Carbohydr. Polym. 2014, 105, 317-324. [CrossRef]

38. De Santis, M.A.; Kosik, O.; Passmore, D.; Flagella, Z.; Shewry, P.R.; Lovegrove, A. Comparison of the dietary fibre composition of old and modern durum wheat (Triticum turgidum spp. durum) genotypes. Food Chem. 2018, 244, 304-310. [CrossRef]

39. Rainakari, A.-I.; Rita, H.; Putkonen, T.; Pastell, H. New dietary fibre content results for cereals in the Nordic countries using AOAC 2011.25 method. J. Food Compos. Anal. 2016, 51, 1-8. [CrossRef]

40. Dodevska, M.S.; Djordjevic, B.I.; Sobajic, S.S.; Miletic, I.D.; Djordjevic, P.B.; Dimitrijevic-Sreckovic, V.S. Characterisation of dietary fibre components in cereals and legumes used in Serbian diet. Food Chem. 2013, 141, 1624-1629. [CrossRef]

41. Šterna, V.; Zute, S.; Jansone, I.; Kantane, I. Chemical Composition of Covered and Naked Spring Barley Varieties and Their Potential for Food Production. Polish J. Food Nutr. Sci. 2017, 67, 151-158. [CrossRef]

42. Vitaglione, P.; Napolitano, A.; Fogliano, V. Cereal dietary fibre: A natural functional ingredient to deliver phenolic compounds into the gut. Trends Food Sci. Technol. 2008, 19, 451-463. [CrossRef]

43. Djurle, S.; Andersson, A.A.M.; Andersson, R. Milling and extrusion of six barley varieties, effects on dietary fibre and starch content and composition. J. Cereal Sci. 2016, 72, 146-152. [CrossRef]

44. Messia, M.C.; Candigliota, T.; De Arcangelis, E.; Marconi, E. Arabinoxylans and $\beta$-glucans assessment in cereals. Ital. J. Food Sci. 2017, 29, 112-122.

45. Hansen, H.B.; Rasmussen, C.V.; Bach Knudsen, K.E.; Hansen, A. Effects of genotype and harvest year on content and composition of dietary fibre in rye (Secale cereale L.) grain. J. Sci. Food Agric. 2003, 83, 76-85. [CrossRef]

46. Amalraj, A.; Pius, A. Influence of oxalate, phytate, tannin, dietary fiber, and cooking on calcium bioavailability of commonly consumed cereals and millets in India. Cereal Chem. 2015, 92, 389-394. [CrossRef]

47. Prasad, V.S.S.; Hymavathi, A.; Babu, V.R.; Longvah, T. Nutritional composition in relation to glycemic potential of popular Indian rice varieties. Food Chem. 2018, 238, 29-34. [CrossRef] [PubMed]

48. Prasanthi, P.S.; Naveena, N.; Vishnuvardhana Rao, M.; Bhaskarachary, K. Compositional variability of nutrients and phytochemicals in corn after processing. J. Food Sci. Technol. 2017, 54, 1080-1090. [CrossRef]

49. Alvarez-Jubete, L.; Arendt, E.K.; Gallagher, E. Nutritive value of pseudocereals and their increasing use as functional gluten-free ingredients. Trends Food Sci. Technol. 2010, 21, 106-113. [CrossRef] 
50. Srichuwong, S.; Curti, D.; Austin, S.; King, R.; Lamothe, L.; Gloria-Hernandez, H. Physicochemical properties and starch digestibility of whole grain sorghums, millet, quinoa and amaranth flours, as affected by starch and non-starch constituents. Food Chem. 2017, 233, 1-10. [CrossRef]

51. Robin, F.; Théoduloz, C.; Srichuwong, S. Properties of extruded whole grain cereals and pseudocereals flours. Int. J. Food Sci. Technol. 2015, 50, 2152-2159. [CrossRef]

52. Pulvento, C.; Riccardi, M.; Lavini, A.; Iafelice, G.; Marconi, E.; D’Andria, R. Yield and Quality Characteristics of Quinoa Grown in Open Field Under Different Saline and Non-Saline Irrigation Regimes. J. Agron. Crop Sci. 2012, 198, 254-263. [CrossRef]

53. Miranda, M.; Vega-Gálvez, A.; Martínez, E.A.; López, J.; Marín, R.; Aranda, M.; Fuentes, F. Influence of contrasting environments on seed composition of two quinoa genotypes: Nutritional and functional properties. Chil. J. Agric. Res. 2013, 73, 6-7. [CrossRef]

54. Steadman, K.J.; Burgoon, M.S.; Lewis, B.A.; Edwardson, S.E.; Obendorf, R.L. Buckwheat seed milling fractions: Description, macronutrient composition and dietary fibre. J. Cereal Sci. 2001, 33, 271-278. [CrossRef]

55. Mir, N.A.; Riar, C.S.; Singh, S. Nutritional constituents of pseudo cereals and their potential use in food systems: A review. Trends Food Sci. Technol. 2018, 75, 170-180. [CrossRef]

56. Zhu, F. Chemical composition and food uses of teff (Eragrostis tef). Food Chem. 2018, 239, 402-415. [CrossRef]

57. Bach Knudsen, K.E.; Munck, L. Dietary fibre contents and compositions of sorghum and sorghum-based foods. J. Cereal Sci. 1985, 3, 153-164. [CrossRef]

58. Jayawardana, S.A.S.; Samarasekera, J.K.R.R.; Hettiarachchi, G.H.C.M.; Gooneratne, J.; Mazumdar, S.D.; Banerjee, R. Dietary fibers, starch fractions and nutritional composition of finger millet varieties cultivated in Sri Lanka. J. Food Compos. Anal. 2019, 82, 103249. [CrossRef]

59. Marcotuli, I.; Hsieh, Y.S.Y.; Lahnstein, J.; Yap, K.; Burton, R.A.; Blanco, A.; Fincher, G.B.; Gadaleta, A. Structural Variation and Content of Arabinoxylans in Endosperm and Bran of Durum Wheat (Triticum turgidum L.). J. Agric. Food Chem. 2016, 64, 2883-2892. [CrossRef]

60. Michelini, E.; Guardigli, M.; Magliulo, M.; Mirasoli, M.; Roda, A.; Simoni, P.; Baraldini, M. Bioluminescent biosensors based on genetically engineered living cells in environmental and food analysis. Anal. Lett. 2006, 39, 1503-1515. [CrossRef]

61. Delcour, J.A.; Van Win, H.; Grobet, P.J. Distribution and structural variation of arabinoxylans in common wheat mill streams. J. Agric. Food Chem. 1999, 47, 271-275. [CrossRef] [PubMed]

62. Dornez, E.; Gebruers, K.; Delcour, J.A.; Courtin, C.M. Grain-associated xylanases: Occurrence, variability, and implications for cereal processing. Trends Food Sci. Technol. 2009, 20, 495-510. [CrossRef]

63. Parker, M.L.; Ng, A.; Waldron, K.W. The phenolic acid and polysaccharide composition of cell walls of bran layers of mature wheat (Triticum aestivum L. cv. Avalon) grains. J. Sci. Food Agric. 2005, 85, 2539-2547. [CrossRef]

64. Saulnier, L.; Sado, P.E.; Branlard, G.; Charmet, G.; Guillon, F. Wheat arabinoxylans: Exploiting variation in amount and composition to develop enhanced varieties. J. Cereal Sci. 2007, 46, 261-281. [CrossRef]

65. Barron, C.; Bar-L'Helgouac'h, C.; Champ, M.; Saulnier, L. Arabinoxylan content and grain tissue distribution are good predictors of the dietary fibre content and their nutritional properties in wheat products. Food Chem. 2020, 328, 8. [CrossRef]

66. Andersson, A.A.M.; Lampi, A.M.; Nyström, L.; Piironen, V.; Li, L.; Ward, J.L.; Gebruers, K.; Courtin, C.M.; Delcour, J.A.; Boros, D.; et al. Phytochemical and dietary fiber components in barley varieties in the HEALTHGRAIN diversity screen. J. Agric. Food Chem. 2008, 56, 9767-9776. [CrossRef]

67. Lazaridou, A.; Biliaderis, C.G. Molecular aspects of cereal $\beta$-glucan functionality: Physical properties, technological applications and physiological effects. J. Cereal Sci. 2007, 46, 101-118. [CrossRef]

68. Vasanthan, T.; Temelli, F. Grain fractionation technologies for cereal beta-glucan concentration. Food Res. Int. 2008, 41, 876-881. [CrossRef]

69. Panfili, G.; Fratianni, A.; Di Criscio, T.; Marconi, E. Tocol and $\beta$-glucan levels in barley varieties and in pearling by-products. Food Chem. 2008, 107, 84-91. [CrossRef]

70. Andersson, R.; Fransson, G.; Tietjen, M.; Åman, P. Content and molecular-weight distribution of dietary fiber components in whole-grain rye flour and bread. J. Agric. Food Chem. 2009, 57, 2004-2008. [CrossRef]

71. Meija, L.; Krams, I. Rye. In Whole Grains and Their Bioactives: Composition and Health; Johnson, J., Wallace, T., Eds.; John Wiley \& Sons: Hoboken, NJ, USA, 2019; pp. 169-208. 
72. Andersson, A.A.M.; Dimberg, L.; Åman, P.; Landberg, R. Recent findings on certain bioactive components in whole grain wheat and rye. J. Cereal Sci. 2014, 59, 294-311. [CrossRef]

73. Rakha, A.; Åman, P.; Andersson, R. Characterisation of dietary fibre components in rye products. Food Chem. 2010, 119, 859-867. [CrossRef]

74. Ji, C.M.; Shin, J.A.; Cho, J.W.; Lee, K.T. Nutritional evaluation of immature grains in two Korean rice cultivars during maturation. Food Sci. Biotechnol. 2013, 22, 903-908. [CrossRef]

75. Fernando, B. Rice as a Source of Fibre. Rice Res. Open Access 2013, 1. [CrossRef]

76. Arendt, E.K.; Zannini, E. Cereal Grains for the Food and Beverage Industries; Woodhead Publishing: Cambridge, UK, 2013.

77. Fletcher, R.J. Pseudocereals: Overview. In Encyclopedia of Food Grains, 2nd ed.; Academic Press: London, UK, 2013; pp. 488-493.

78. Velarde-Salcedo, A.J.; Bojórquez-Velázquez, E.; de la Rosa, A.P.B. Amaranth. In Whole Grains and Their Bioactives: Composition and Health; Johnson, J., Wallace, T., Eds.; John Wiley \& Sons: Hoboken, NJ, USA, 2019; pp. 209-250.

79. Reguera, M.; Haros, C.M. Structure and Composition of Kernels. In Pseudocereals: Chemistry and Technology; John Wiley \& Sons: Hoboken, NJ, USA, 2016; pp. 28-48.

80. Prego, I.; Maldonado, S.; Otegui, M. Seed structure and localization of reserves in Chenopodium quinoa. Ann. Bot. 1998, 82, 481-488. [CrossRef]

81. Izydorczyk, M.S.; McMillan, T.; Bazin, S.; Kletke, J.; Dushnicky, L.; Dexter, J. Canadian buckwheat: A unique, useful and under-utilized crop. Can. J. Plant Sci. 2014, 94, 509-524. [CrossRef]

82. Izydorczyk, M.S.; Head, D. Characterization and Potential Uses of Functional Buckwheat Fractions Obtained by Roller Milling of New Canadian Buckwheat Genotypes. Eur. J. Plant Sci. Biotechnol. 2010, 4, 71-81.

83. Alvarez-Jubete, L.; Arendt, E.K.; Gallagher, E. Nutritive value and chemical composition of pseudocereals as gluten-free ingredients. Int. J. Food Sci. Nutr. 2009, 60, 240-257. [CrossRef]

84. Mustafa, A.F.; Seguin, P.; Gélinas, B.; Gé Linas, B. Chemical composition, dietary fibre, tannins and minerals of grain amaranth genotypes. Int. J. Food Sci. Nutr. 2011, 62, 750-754. [CrossRef]

85. Lamothe, L.M.; Srichuwong, S.; Reuhs, B.L.; Hamaker, B.R. Quinoa (Chenopodium quinoa W.) and amaranth (Amaranthus caudatus L.) provide dietary fibres high in pectic substances and xyloglucans. Food Chem. 2015, 167, 490-496. [CrossRef]

86. Haros, C.M.; Schonlechner, R. Pseudocereals: Chemistry and Technology; Schonlechner, C.M.H.R., Ed.; John Wiley \& Sons: Hoboken, NJ, USA, 2016.

87. Huang, T.; Xu, M.; Lee, A.; Cho, S.; Qi, L. Consumption of whole grains and cereal fiber and total and cause-specific mortality: Prospective analysis of 367,442 individuals. BMC Med. 2015, 13. [CrossRef]

88. Low Wang, C.C.; Hess, C.N.; Hiatt, W.R.; Goldfine, A.B. Clinical update: Cardiovascular disease in diabetes mellitus. Circulation 2016, 133, 2459-2502. [CrossRef] [PubMed]

89. Wang, L.; Sikand, G.; Wong, N.D. Nutrition, Diet Quality, and Cardiovascular Health. In Molecular Basis of Nutrition and Aging: A Volume in the Molecular Nutrition Series; Academic Press: London, UK, 2016; pp. 315-330.

90. Anderson, J.W.; Baird, P.; Davis, R.H.; Ferreri, S.; Knudtson, M.; Koraym, A.; Waters, V.; Williams, C.L. Health benefits of dietary fiber. Nutr. Rev. 2009, 67, 188-205. [CrossRef] [PubMed]

91. Slavin, J.L.; Martini, M.C.; Jacobs, D.R.; Marquart, L. Plausible mechanisms for the protectiveness of whole grains. Am. J. Clin. Nutr. 1999, 70, 459s-463s. [CrossRef] [PubMed]

92. Prasad, K.N.; Bondy, S.C. Dietary fibers and their fermented short-chain fatty acids in prevention of human diseases. Bioact. Carbohydrates Diet. Fibre 2019, 17. [CrossRef]

93. CFR. CFR—Code of Federal Regulations Title 21. Available online: http://www.accessdata.fda.gov/scripts/ cdrh/cfdocs/cfcfr/CFRSearch.cfm?fr=50.25 (accessed on 21 June 2020).

94. Broekaert, W.F.; Courtin, C.M.; Verbeke, K.; van de Wiele, T.; Verstraete, W.; Delcour, J.A. Prebiotic and other health-related effects of cereal-derived arabinoxylans, arabinoxylan-oligosaccharides, and xylooligosaccharides. Crit. Rev. Food Sci. Nutr. 2011, 51, 178-194. [CrossRef]

95. Tong, L.T.; Zhong, K.; Liu, L.; Qiu, J.; Guo, L.; Zhou, X.; Cao, L.; Zhou, S. Effects of dietary wheat bran arabinoxylans on cholesterol metabolism of hypercholesterolemic hamsters. Carbohydr. Polym. 2014, 112, 1-5. [CrossRef] 
96. Kieffer, D.A.; Piccolo, B.D.; Marco, M.L.; Kim, E.B.; Goodson, M.L.; Keenan, M.J.; Dunn, T.N.; Knudsen, K.E.B.; Adams, S.H.; Martin, R.J. Obese Mice Fed a Diet Supplemented with Enzyme-Treated Wheat Bran Display Marked Shifts in the Liver Metabolome Concurrent with Altered Gut Bacteria. J. Nutr. 2016, 146, 2445-2460. [CrossRef]

97. Adam, A.; Levrat-Verny, M.-A.; Lopez, H.W.; Leuillet, M.; Demigné, C.; Rémésy, C. Whole Wheat and Triticale Flours with Differing Viscosities Stimulate Cecal Fermentations and Lower Plasma and Hepatic Lipids in Rats. J. Nutr. 2001, 131, 1770-1776. [CrossRef]

98. Konishi, Y.; Arai, N.; Umeda, J.; Gunji, N.; Saeki, S.; Takao, T.; Minoguchi, R.; Kensho, G. Cholesterol lowering effect of the methanol insoluble materials from the quinoa seed pericarp. In Hydrocolloids; Elsevier Science: Amsterdam, The Netherlands, 2000; pp. 417-422.

99. Plate, A.Y.; Aréas, J.A.G. Cholesterol-lowering effect of extruded amaranth (Amaranthus caudatus L.) in hypercholesterolemic rabbits. Food Chem. 2002, 76, 1-6. [CrossRef]

100. Liu, S.; Stampfer, M.J.; Hu, F.B.; Giovannucci, E.; Rimm, E.; Manson, J.A.E.; Hennekens, C.H.; Willett, W.C. Whole-grain consumption and risk of coronary heart disease: Results from the Nurses' Health Study. Am. J. Clin. Nutr. 1999, 70, 412-419. [CrossRef] [PubMed]

101. Franco, B.M.; Latre, M.L.; Esteban, E.M.A.; Ordov ás, J.M.; Casasnovas, J.A.; Peñalvo, J.L. Ingesta de fibra soluble e insoluble y factores de riesgo de síndrome metabólico y enfermedad cardiovascular en adultos de mediana edad: La cohorte AWHS. Nutr. Hosp. 2014, 30, 1279-1288.

102. Keenan, J.M.; Goulson, M.; Shamliyan, T.; Knutson, N.; Kolberg, L.; Curry, L. The effects of concentrated barley $\beta$-glucan on blood lipids in a population of hypercholesterolaemic men and women. Br. J. Nutr. 2007, 97, 1162-1168. [CrossRef] [PubMed]

103. Behall, K.M.; Scholfield, D.J.; Hallfrisch, J. Diets Containing Barley Significantly Reduce Lipids in Mildly Hypercholesterolemic Men and Women. Am. J. Clin. Nutr. 2004, 80, 1185-1193. [CrossRef]

104. Whitehead, A.; Beck, E.J.; Tosh, S.; Wolever, T.M. Cholesterol-lowering effects of oat $\beta$-glucan: A meta-analysis of randomized controlled trials. Am. J. Clin. Nutr. 2014, 100, 1413-1421. [CrossRef]

105. Goverment of Canada. Hypertension Facts and Figures-Canada.ca. Available online: https://www.canada. ca/en/public-health/services/chronic-diseases/cardiovascular-disease/hypertension-facts-figures.html (accessed on 21 September 2020).

106. Aljuraiban, G.S.; Griep, L.M.O.; Griep, L.M.O.; Chan, Q.; Daviglus, M.L.; Stamler, J.; Van Horn, L.; Elliott, P.; Frost, G.S. Total, insoluble and soluble dietary fibre intake in relation to blood pressure: The INTERMAP Study. Br. J. Nutr. 2015, 114, 1480-1486. [CrossRef]

107. Streppel, M.T.; Arends, L.R.; Van't Veer, P.; Grobbee, D.E.; Geleijnse, J.M. Dietary fiber and blood pressure: A meta-analysis of randomized placebo-controlled trials. Arch. Intern. Med. 2005, 165, 150-156. [CrossRef]

108. Razavi, A.C.; Bazzano, L.A.; He, J.; Whelton, S.P.; Fernandez, C.; Ley, S.; Qi, L.; Krousel-Wood, M.; Harlan, T.S.; Kelly, T.N. Consumption of animal and plant foods and risk of left ventricular diastolic dysfunction: The Bogalusa Heart Study. ESC Hear. Fail. 2020, 7, 2700-2710. [CrossRef]

109. Alonso, A.; Beunza, J.J.; Bes-Rastrollo, M.; Pajares, R.M.; Martínez-González, M.Á. Vegetable Protein and Fiber from Cereal Are Inversely Associated with the Risk of Hypertension in a Spanish Cohort. Arch. Med. Res. 2006, 37, 778-786. [CrossRef]

110. Keenan, J.M.; Pins, J.J.; Frazel, C.; Moran, A.; Turnquist, L. Oat ingestion reduces systolic and diastolic blood pressure in patients with mild or borderline hypertension: A pilot trial. J. Fam. Pract. 2002, 51, 369.

111. El Khoury, D.; Cuda, C.; Luhovyy, B.L.; Anderson, G.H. Beta glucan: Health benefits in obesity and metabolic syndrome. J. Nutr. Metab. 2012, 2012. [CrossRef] [PubMed]

112. Government of Canada. Diabetes in Canada-Canada.ca. Available online: https://www.canada.ca/ en/public-health/services/publications/diseases-conditions/diabetes-canada-highlights-chronic-diseasesurveillance-system.html (accessed on 22 June 2020).

113. Reynolds, A.N.; Akerman, A.P.; Mann, J. Dietary fibre and whole grains in diabetes management: Systematic review and meta-analyses. PLoS Med. 2020, 17, e1003053. [CrossRef] [PubMed]

114. Garcia, A.L.; Otto, B.; Reich, S.C.; Weickert, M.O.; Steiniger, J.; Machowetz, A.; Rudovich, N.N.; Möhlig, M.; Katz, N.; Speth, M.; et al. Arabinoxylan consumption decreases postprandial serum glucose, serum insulin and plasma total ghrelin response in subjects with impaired glucose tolerance. Eur. J. Clin. Nutr. 2007, 61, 334-341. [CrossRef] [PubMed] 
115. Henrion, M.; Francey, C.; Lê, K.A.; Lamothe, L. Cereal B-glucans: The impact of processing and how it affects physiological responses. Nutrients 2019, 11, 1729. [CrossRef] [PubMed]

116. Mälkki, Y.; Virtanen, E. Gastrointestinal Effects of Oat Bran and Oat Gum: A Review. LWT Food Sci. Technol. 2001, 34, 337-347. [CrossRef]

117. Li, L.; Pan, M.; Pan, S.; Li, W.; Zhong, Y.; Hu, J.; Nie, S. Effects of insoluble and soluble fibers isolated from barley on blood glucose, serum lipids, liver function and caecal short-chain fatty acids in type 2 diabetic and normal rats. Food Chem. Toxicol. 2020, 135, 110937. [CrossRef]

118. Schulze, M.B.; Schulz, M.; Heidemann, C.; Schienkiewitz, A.; Hoffmann, K.; Boeing, H. Fiber and magnesium intake and incidence of type 2 diabetes: A prospective study and meta-analysis. Arch. Intern. Med. 2007, 167, 956-965. [CrossRef]

119. Davison, K.M.; Temple, N.J. Cereal fiber, fruit fiber, and type 2 diabetes: Explaining the paradox. J. Diabetes Complicat. 2018, 32, 240-245. [CrossRef]

120. Kim, H.K.; Kim, M.J.; Cho, H.Y.; Kim, E.K.; Shin, D.H. Antioxidative and anti-diabetic effects of amaranth (Amaranthus esculantus) in streptozotocin-induced diabetic rats. Cell Biochem. Funct. 2006, 24, 195-199. [CrossRef]

121. Capriles, V.D.; Coelho, K.D.; Guerra-Matias, A.C.; Arêas, J.A.G. Effects of Processing Methods on Amaranth Starch Digestibility and Predicted Glycemic Index. J. Food Sci. 2008, 73, 160-164. [CrossRef]

122. The InterAct Consortium Dietary fibre and incidence of type 2 diabetes in eight European countries: The EPIC-InterAct Study and a meta-analysis of prospective studies. Epic. Study Meta Anal. Prospect. Stud. 2015, $58,1394-1408$.

123. Braaten, J.T.; Scott, F.W.; Wood, P.J.; Riedel, K.D.; Wolynetz, M.S.; Brulé, D.; Collins, M.W. High beta-glucan oat bran and oat gum reduce postprandial blood glucose and insulin in subjects with and without type 2 diabetes. Diabet. Med. 1994, 11, 312-318. [CrossRef] [PubMed]

124. Shen, X.; Zhao, T.; Zhou, Y.; Shi, X.; Zou, Y.; Zhao, G. Effect of Oat $\beta$-Glucan Intake on Glycaemic Control and Insulin Sensitivity of Diabetic Patients: A Meta-Analysis of Randomized Controlled Trials. Nutrients 2016, 8, 39. [CrossRef] [PubMed]

125. Chen, Z.; Li, S.; Fu, Y.; Li, C.; Chen, D.; Chen, H. Arabinoxylan structural characteristics, interaction with gut microbiota and potential health functions. J. Funct. Foods 2019, 54, 536-551. [CrossRef]

126. Giulia Falchi, A.; Grecchi, I.; Muggia, C.; Palladini, G.; Perlini, S. Effects of a Bioavailable Arabinoxylan-enriched White Bread Flour on Postprandial Glucose Response in Normoglycemic Subjects. J. Diet. Suppl. 2016, 13, 626-633. [CrossRef]

127. Juvonen, K.R.; Purhonen, A.-K.; Salmenkallio-Marttila, M.; Lähteenmäki, L.; Laaksonen, D.E.; Herzig, K.-H.; Uusitupa, M.I.J.; Poutanen, K.S.; Karhunen, L.J. Viscosity of Oat Bran-Enriched Beverages Influences Gastrointestinal Hormonal Responses in Healthy Humans. J. Nutr. 2009, 139, 461-466. [CrossRef]

128. Kellow, N.J.; Walker, K.Z. Authorised EU health claim for arabinoxylan. In Foods, Nutrients and Food Ingredients with Authorised EU Health Claims; Woodhead Publishing: Cambridge, UK, 2018; Volume 3, pp. 201-218.

129. Weickert, M.O.; Pfeiffer, A.F.H. Metabolic effects of dietary fiber consumption and prevention of diabetes. J. Nutr. 2008, 138, 439-442. [CrossRef]

130. Feldman, A.L.; Long, G.H.; Johansson, I.; Weinehall, L.; Fhärm, E.; Wennberg, P.; Norberg, M.; Griffin, S.J.; Rolandsson, O. Change in lifestyle behaviors and diabetes risk: Evidence from a population-based cohort study with 10 year follow-up. Int. J. Behav. Nutr. Phys. Act. 2017, 14, 39. [CrossRef]

131. Honsek, C.; Kabisch, S.; Kemper, M.; Gerbracht, C.; Arafat, A.M.; Birkenfeld, A.L.; Dambeck, U.; Osterhoff, M.A.; Weickert, M.O.; Pfeiffer, A.F.H. Fibre supplementation for the prevention of type 2 diabetes and improvement of glucose metabolism: The randomised controlled Optimal Fibre Trial (OptiFiT). Diabetologia 2018, 61, 1295-1305. [CrossRef]

132. Davani-Davari, D.; Negahdaripour, M.; Karimzadeh, I.; Seifan, M.; Mohkam, M.; Masoumi, S.J.; Berenjian, A.; Ghasemi, Y. Prebiotics: Definition, Types, Sources, Mechanisms, and Clinical Applications. Foods 2019, 8, 92. [CrossRef]

133. Colorectal Cancer Statistics-Canadian Cancer Society. Available online: https://www.cancer.ca/en/cancerinformation/cancer-type/colorectal/statistics/region=on (accessed on 22 June 2020).

134. Kaczmarczyk, M.M.; Miller, M.J.; Freund, G.G. The health benefits of dietary fiber: Beyond the usual suspects of type 2 diabetes mellitus, cardiovascular disease and colon cancer. Metabolism 2012, 61, 1058-1066. [CrossRef] [PubMed] 
135. Oh, H.; Kim, H.; Lee, D.H.; Lee, A.; Giovannucci, E.L.; Kang, S.S.; Keum, N. Different dietary fibre sources and risks of colorectal cancer and adenoma: A dose-response meta-analysis of prospective studies. $\mathrm{Br}$. J. Nutr. 2019, 122, 605-615. [CrossRef] [PubMed]

136. Zyła, E.; Dziendzikowska, K.; Gajewska, M.; Wilczak, J.; Harasym, J.; Gromadzka-Ostrowska, J. Beneficial effects of oat beta-glucan dietary supplementation in colitis depend on its molecular weight. Molecules 2019, 24, 3591. [CrossRef] [PubMed]

137. Health Canada. Inflammatory Bowel Disease (IBD)—Canada.ca. Available online: https://www.canada.ca/ en/public-health/services/chronic-diseases/inflammatory-bowel-disease.html (accessed on 15 July 2020).

138. Suchecka, D.; Harasym, J.P.; Wilczak, J.; Gajewska, M.; Oczkowski, M.; Gudej, S.; Błaszczyk, K.; Kamola, D.; Filip, R.; Gromadzka-Ostrowska, J. Antioxidative and anti-inflammatory effects of high beta-glucan concentration purified aqueous extract from oat in experimental model of LPS-induced chronic enteritis. J. Funct. Foods 2015, 14, 244-254. [CrossRef]

139. Andersen, V.; Chan, S.; Luben, R.; Khaw, K.-T.; Olsen, A.; Tjonneland, A.; Kaaks, R.; Grip, O.; Bergmann, M.M.; Boeing, H.; et al. Fibre intake and the development of inflammatory bowel disease: A European prospective multi-centre cohort study (EPIC-IBD). J. Crohn's Colitis 2018, 12, 129-136. [CrossRef]

140. Ananthakrishnan, A.N.; Khalili, H.; Konijeti, G.G.; Higuchi, L.M.; De Silva, P.; Korzenik, J.R.; Fuchs, C.S.; Willett, W.C.; Richter, J.M.; Chan, A.T. A prospective study of long-term intake of dietary fiber and risk of Crohn's disease and ulcerative colitis. Gastroenterology 2013, 145, 970-977. [CrossRef]

141. O'Grady, J.; O'Connor, E.M.; Shanahan, F. Review article: Dietary fibre in the era of microbiome science. Aliment. Pharmacol. Ther. 2019, 49, 506-515. [CrossRef]

142. Lin, D.; Peters, B.A.; Friedlander, C.; Freiman, H.J.; Goedert, J.J.; Sinha, R.; Miller, G.; Bernstein, M.A.; Hayes, R.B.; Ahn, J. Association of dietary fibre intake and gut microbiota in adults. Br. J. Nutr. 2018, 120, 1014-1022. [CrossRef]

143. Martens, E.C. Microbiome: Fibre for the future. Nature 2016, 529, 158-159. [CrossRef]

144. Sonnenburg, E.D.; Smits, S.A.; Tikhonov, M.; Higginbottom, S.K.; Wingreen, N.S.; Sonnenburg, J.L. Diet-induced extinctions in the gut microbiota compound over generations. Nature 2016, 529, $212-215$. [CrossRef]

145. El Kaoutari, A.; Armougom, F.; Gordon, J.I.; Raoult, D.; Henrissat, B. The abundance and variety of carbohydrate-active enzymes in the human gut microbiota. Nat. Rev. Microbiol. 2013, 11, 497-504. [CrossRef] [PubMed]

146. Ho, Y.H.; Tan, M.; Seow-Choen, F. Micronized purified flavonidic fraction compared favorably with rubber band ligation and fiber alone in the management of bleeding hemorrhoids: Randomized controlled trial. Dis. Colon Rectum 2000, 43, 66-69. [CrossRef] [PubMed]

147. Cummings, J.H. The effect of dietary fiber on fecal weight and composition. In CRC Handbook of Dietary Fiber in Human Nutrition, 3rd ed.; CRC Press: Boca Raton, FL, USA, 2001; pp. 183-252.

148. Smith, C.E.; Tucker, K.L. Health benefits of cereal fibre: A review of clinical trials. Nutr. Res. Rev. 2011, 24, 118-131. [CrossRef] [PubMed]

149. van de Vijver, L.P.L.; van den Bosch, L.M.C.; van den Brandt, P.A.; Goldbohm, R.A. Whole-grain consumption, dietary fibre intake and body mass index in the Netherlands cohort study. Eur. J. Clin. Nutr. 2009, 63, 31-38. [CrossRef]

150. Kromhout, D.; Bloemberg, B.; Seidell, J.C.; Nissinen, A.; Menotti, A. Physical activity and dietary fiber determine population body fat levels: The Seven Countries Study. Int. J. Obes. Relat. Metab. Disord. 2001, 25, 301-306. [CrossRef]

151. Vitaglione, P.; Lumaga, R.B.; Stanzione, A.; Scalfi, L.; Fogliano, V. $\beta$-Glucan-enriched bread reduces energy intake and modifies plasma ghrelin and peptide YY concentrations in the short term. Appetite 2009, 53, 338-344. [CrossRef]

152. Aoe, S.; Ikenaga, T.; Noguchi, H.; Kohashi, C.; Kakumoto, K.; Kohda, N. Effect of Cooked White Rice with High $\beta$-glucan Barley on Appetite and Energy Intake in Healthy Japanese Subjects: A Randomized Controlled Trial. Plant Foods Hum. Nutr. 2014, 69, 325-330. [CrossRef]

153. Rahmani, J.; Miri, A.; Černevičiūtè, R.; Thompson, J.; de Souza, N.N.; Sultana, R.; Kord Varkaneh, H.; Mousavi, S.M.; Hekmatdoost, A. Effects of cereal beta-glucan consumption on body weight, body mass index, waist circumference and total energy intake: A meta-analysis of randomized controlled trials. Complement. Ther. Med. 2019, 43, 131-139. [CrossRef] 
154. Hoad, C.L.; Rayment, P.; Spiller, R.C.; Marciani, L.; de Celis, A.B.; Traynor, C.; Mela, D.J.; Peters, H.P.F.; Gowland, P.A. In Vivo Imaging of Intragastric Gelation and Its Effect on Satiety in Humans. J. Nutr. 2004, 134, 2293-2300. [CrossRef]

155. Beck, E.J.; Tosh, S.M.; Batterham, M.J.; Tapsell, L.C.; Huang, X.F. Oat $\beta$-glucan increases postprandial cholecystokinin levels, decreases insulin response and extends subjective satiety in overweight subjects. Mol. Nutr. Food Res. 2009, 53, 1343-1351. [CrossRef]

156. Baye, K.; Guyot, J.P.; Mouquet-Rivier, C. The unresolved role of dietary fibers on mineral absorption. Crit. Rev. Food Sci. Nutr. 2017, 57, 949-957. [CrossRef] [PubMed]

157. Miyada, T.; Nakajima, A.; Ebihara, K. Iron bound to pectin is utilised by rats. Br. J. Nutr. 2011, 106, 73-78. [CrossRef] [PubMed]

158. Khokhar, S.; Kapoor, A.C. Effect of dietary fibres on bioavailability of vitamin A and thiamine. Plant Foods Hum. Nutr. 1990, 40, 259-265. [CrossRef] [PubMed]

159. Kurek, M.A.; Wyrwisz, J.; Karp, S.; Wierzbicka, A. Particle size of dietary fiber preparation affects the bioaccessibility of selected vitamin B in fortified wheat bread. J. Cereal Sci. 2017, 77, 166-171. [CrossRef]

160. Riedl, J.; Linseisen, J.; Hoffmann, J.; Wolfram, G. Some dietary fibers reduce the absorption of carotenoids in women. J. Nutr. 1999, 129, 2170-2176. [CrossRef]

(C) 2020 by the authors. Licensee MDPI, Basel, Switzerland. This article is an open access article distributed under the terms and conditions of the Creative Commons Attribution (CC BY) license (http://creativecommons.org/licenses/by/4.0/). 